مقايسه كارايى روشهاى وزندهى شواهد، رگرسيون لجستيك و نسبت فراوانى در تهيه نقشه يتانسيل جشمه آب زيرزمينى در حوزه آبخيز جهل گزىى، استان كردستان

مهدى عرفانيان'، هانا فرج اللهى'، مهشيد سورى'و عطاله شيرزادى ب**

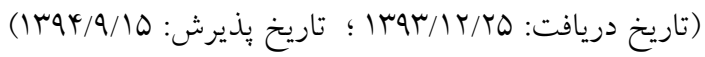

جكيده

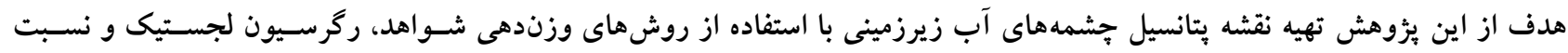

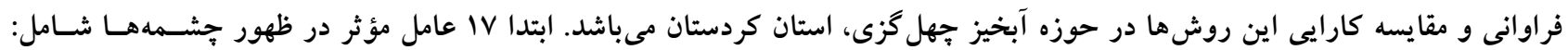

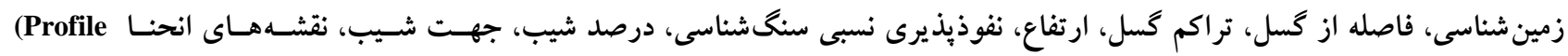
توبركاف، Curvature, Curvature, Plan Curvature)

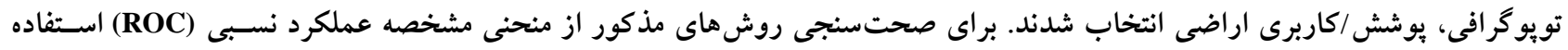

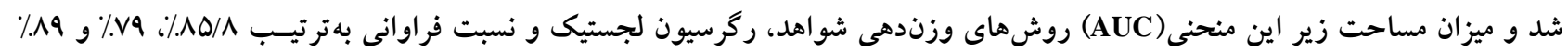

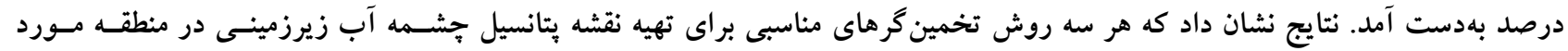

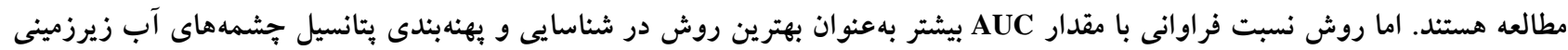

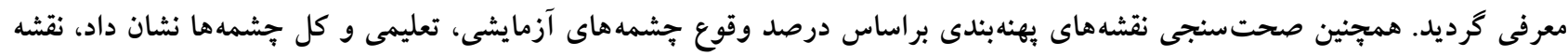

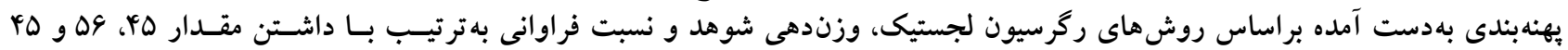

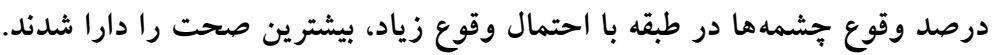

وازگَان كليدى: جشمه آب زيرزمينى، وزندهى شواهد، رگرسيون لجستيك، نسبت فراوانى، ROC، حوزه جهل گزى

ا. (. كروه مهندسى آبخيزدارى، دانشكده منابع طبيعى، دانشكاه اروميه

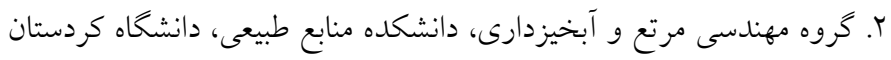

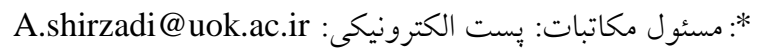


كه نشان داد روش نسبت فراوانى و وزندهى شواهد نسـبت بـهـ

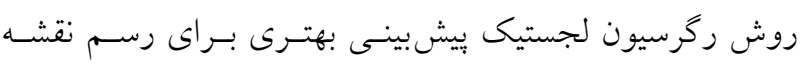

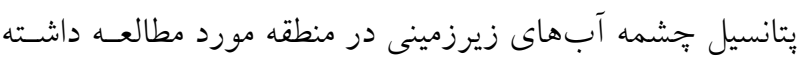

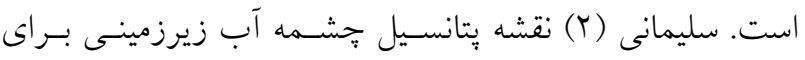

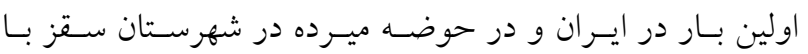

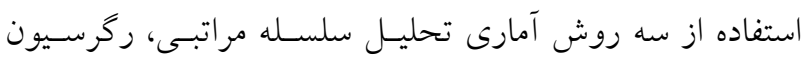

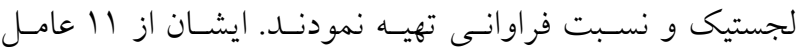

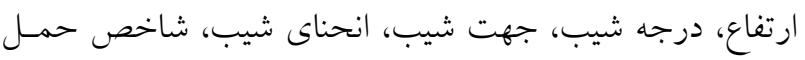

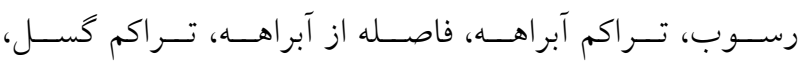

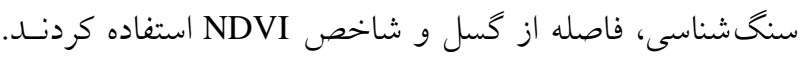

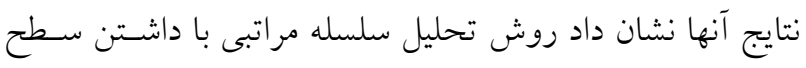

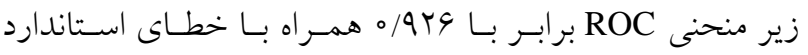

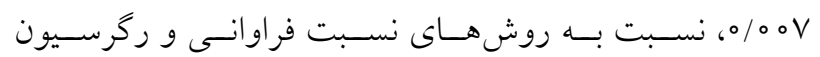

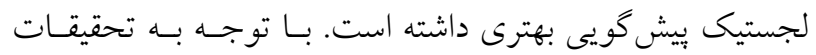

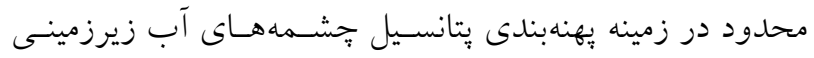

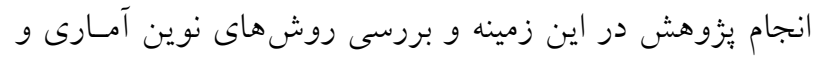

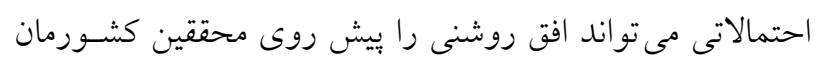

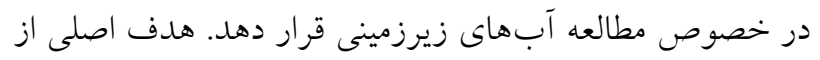

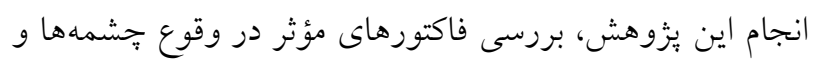

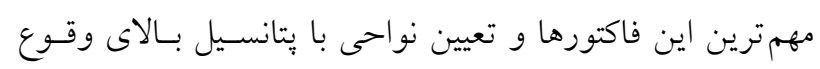
جشمههاى آب زيرزمينى در منطقه مورد مطالعه مى باشد.

\section{مواد و روشها - ماد}

موقعيت جغر افيايى و خصوصيات فيزيكى، زمسين شناسسى و اقليمى منطقه مورد مطالعه

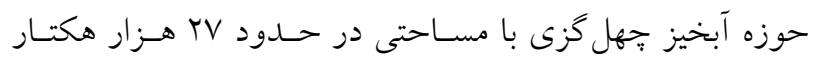

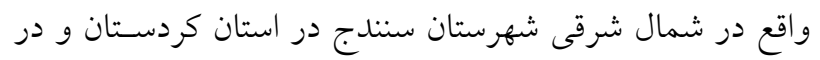
محدوده مختصات جغر افيايى 'Oه

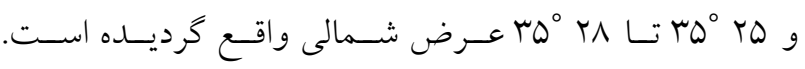

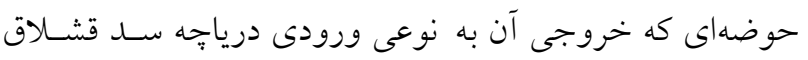

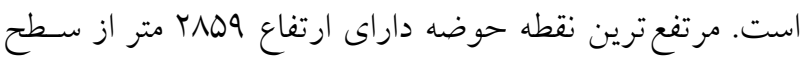

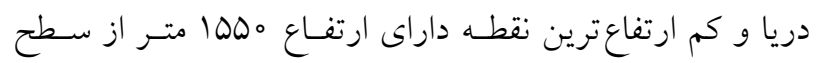

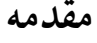
با توجه به نيازهاى انسان به آب، تلاش براى رسيدن به منابع آب

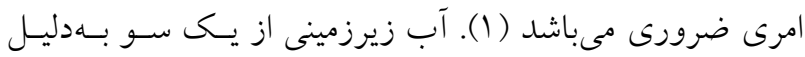

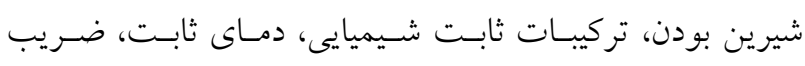

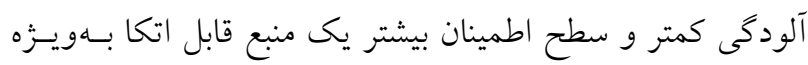

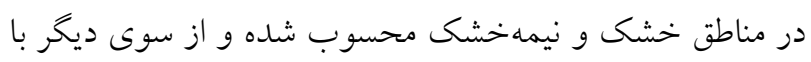

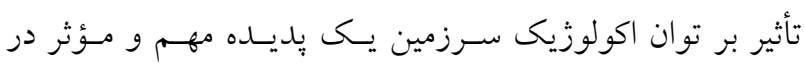

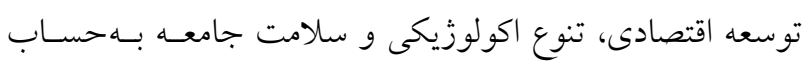

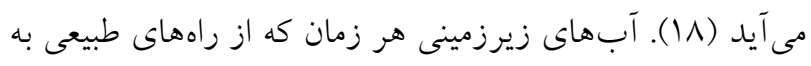

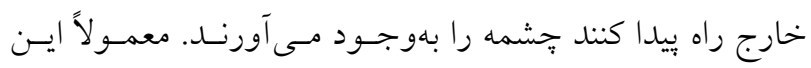

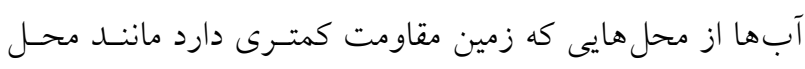

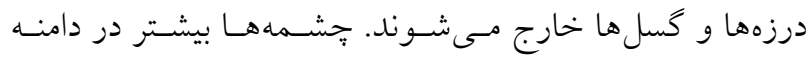
كوهها و كف درهها ظاهر مىشوند. بعضى جشى جشـمههــا در تمـام

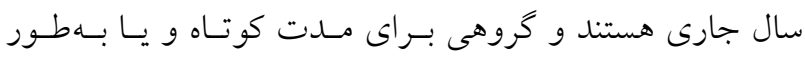

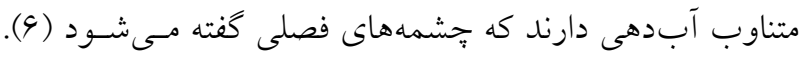

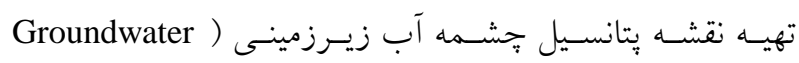
Spring Potential (GSP) كه تأمين كننده آب مورد نياز جهت مصارف شرب، كشاورزى و صنعت هستند را در زمان خشكسالى فراهم مى ســازد. همجِنسين

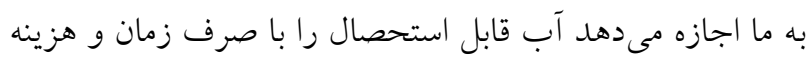

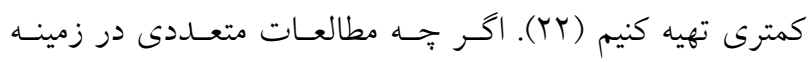

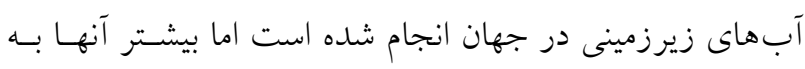

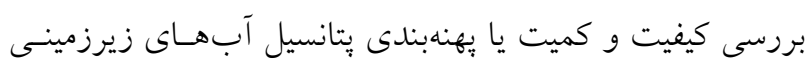

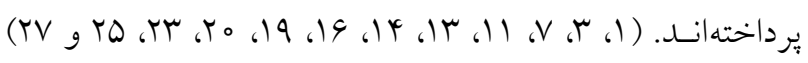

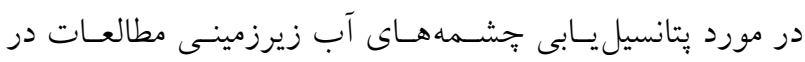

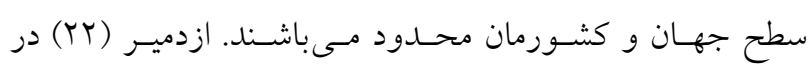

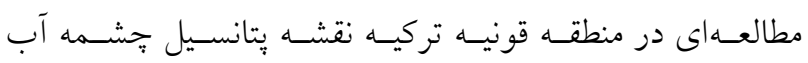

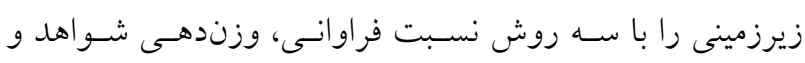

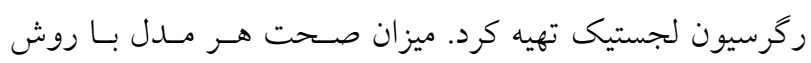

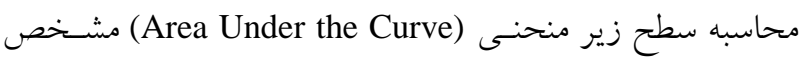
شد. مقدار AUC در روش هاى نسبت فراو انى، وزندهى شئس شواهد

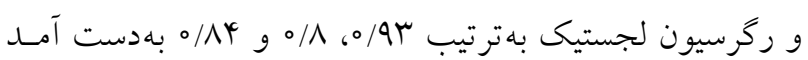



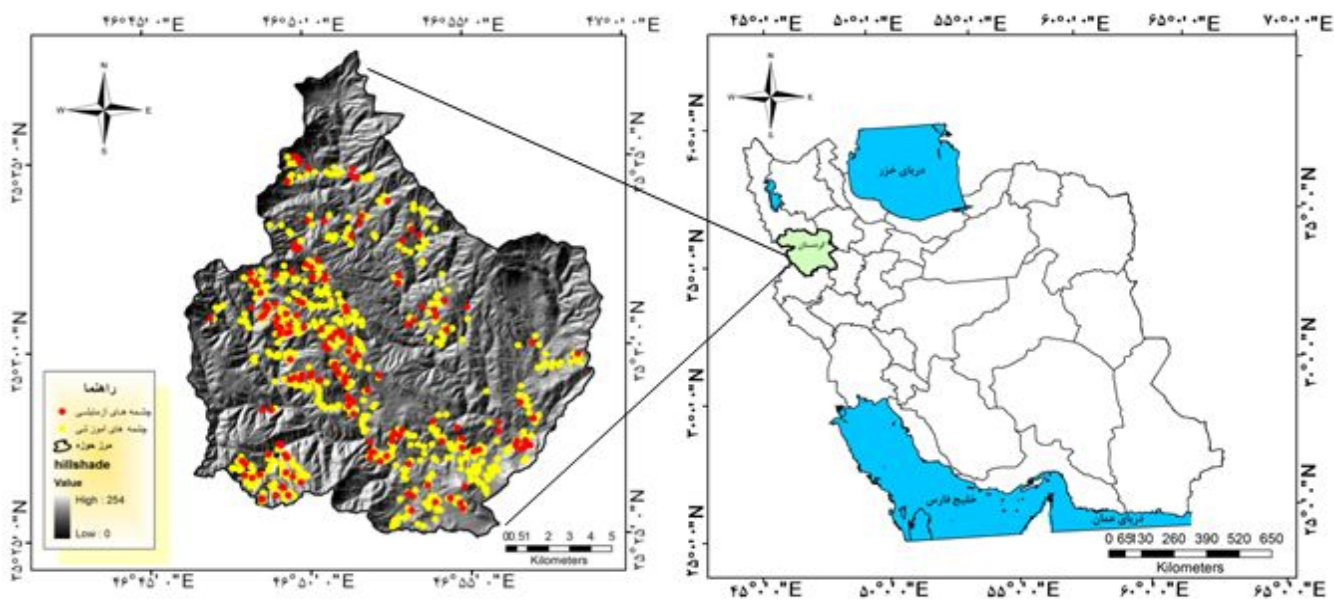

شكل ا. موقعيت جغرافيايى حوزه آبخيز جهال گزىى و موقعيت جشمهها در ايران و استان كردستان

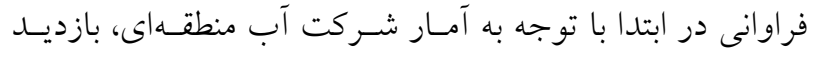

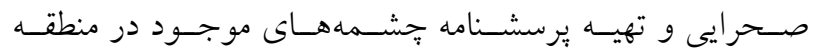

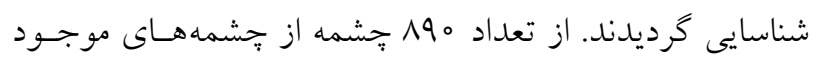

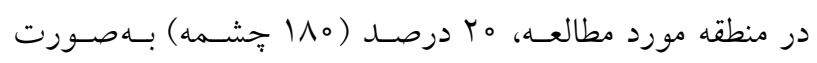

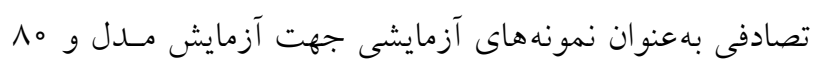

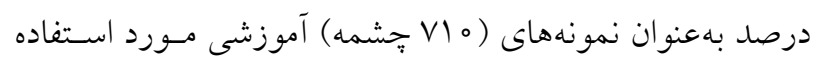

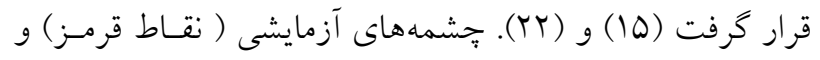

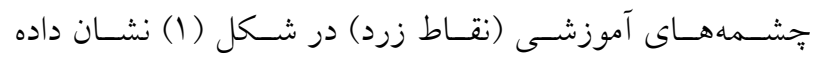

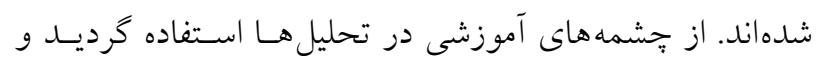

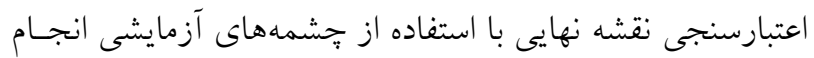

\section{نقشه عوامل مؤثر بر ظهور جشمهها}

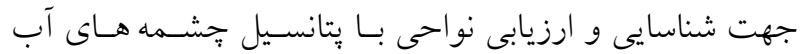

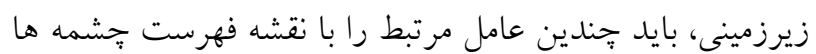

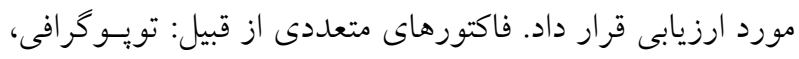

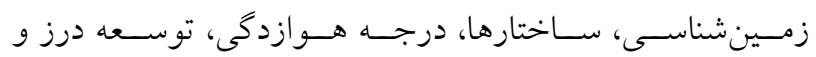

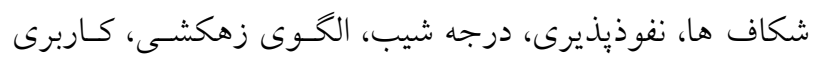

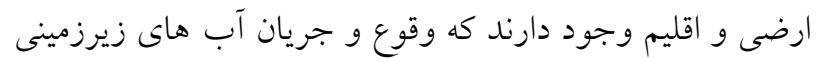

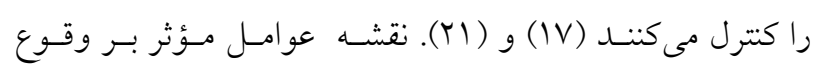
جشمه ها شامل؛ درجه شيب، جهـت دامنـه، شـكل هــاى شـيب،

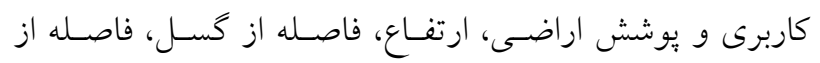

دريا مىباشد. تيـي اراضسى در ايسن منطقـه اغلـب كوهستانى،

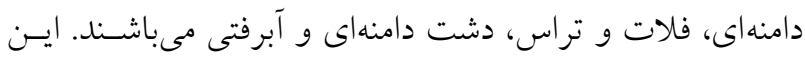

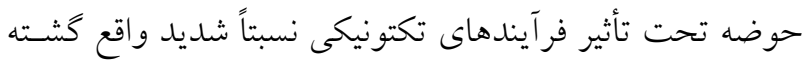

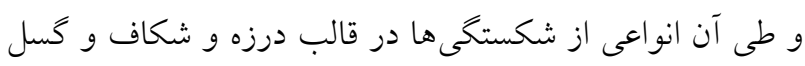

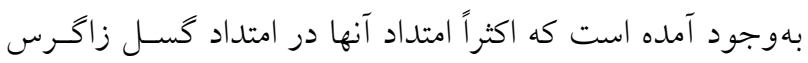

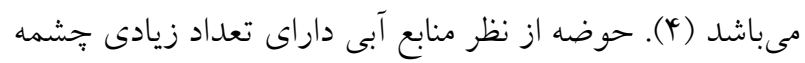

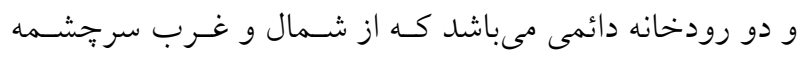

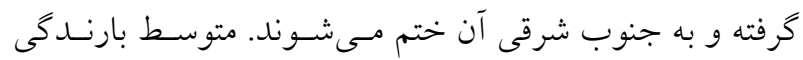

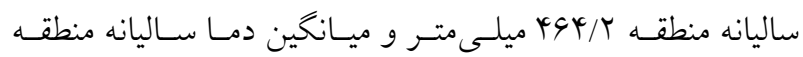

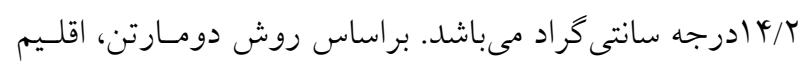

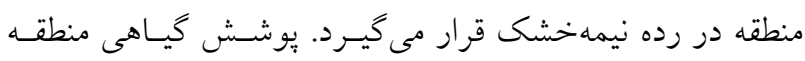

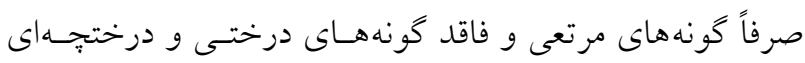

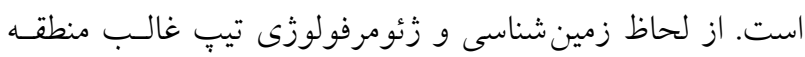

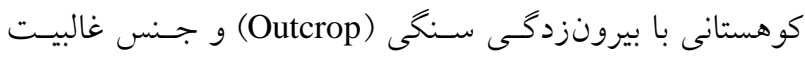

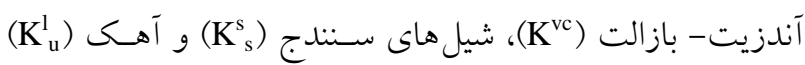

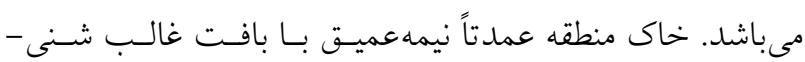
لومى و در رده آنتى سول جاى دارند. شكل (1) موقعيت منطقسهـ مورد مطالعه را نشان مىدهد.

\section{نقشه موقعيت جشمه هاى آب زيرزمينى}

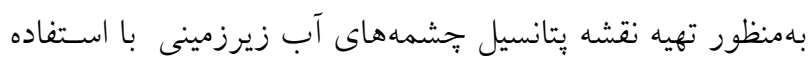

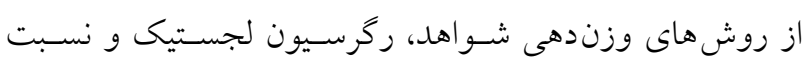


استوار است (TV). وزنها در اين روش براساس وجود يـا عـدم

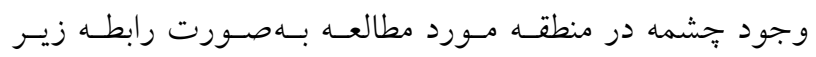
محاسبه مى گردد:

$\mathrm{W}^{+}=\ln \left(\frac{\mathrm{P}(\mathrm{F} / \mathrm{S})}{\mathrm{P}\left(\mathrm{F} / \mathrm{S}^{*}\right.}\right)$

$\mathrm{W}^{-}=\ln \left(\frac{\mathrm{P}\left(\mathrm{F}^{*} / \mathrm{S}\right)}{\mathrm{P}\left(\mathrm{F}^{*} / \mathrm{S}^{*}\right.}\right)$

$\mathrm{C}=\mathrm{W}^{+}-\mathrm{W}^{-}$

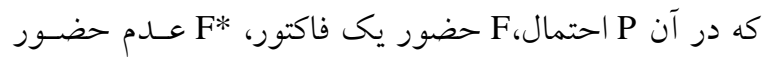
يكى فاكتور، S حضور جشمه و S* عدم حضور جشـمه استـ.

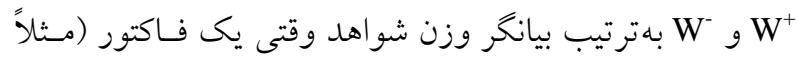

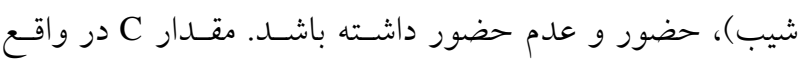

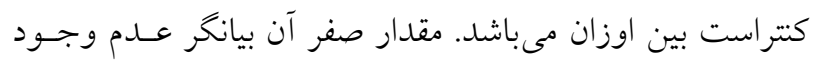

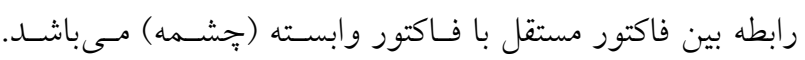

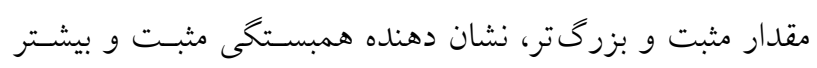

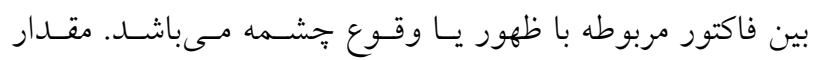
احتمال بِين P(s) از روابط زير بهدست مى آيد:

$\ln (\mathrm{P}(\mathrm{s}))=\left\{\sum \mathrm{W}^{+}+\operatorname{Ln}\left(\mathrm{P}_{\mathrm{p}}(\mathrm{s})\right)\right\}$

$\mathrm{GSP}_{\mathrm{WOE}}=\mathrm{P}(\mathrm{s})=\exp \left\{\sum \mathrm{W}^{+}+\ln \left(\mathrm{P}_{\mathrm{p}}(\mathrm{s})\right)\right\}$

كه در آن Probability) احتمال يِيشين Prior Prow بـوده و

$$
\text { از رابطه زير بهدست مى آيد: }
$$

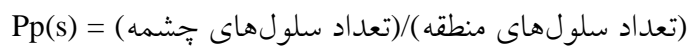

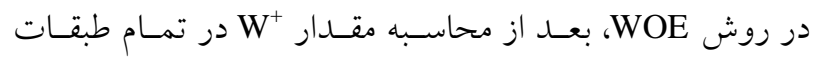

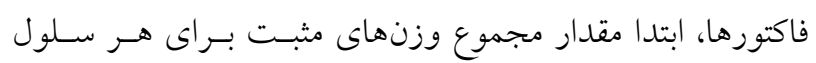

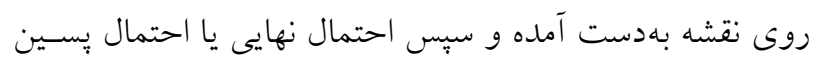

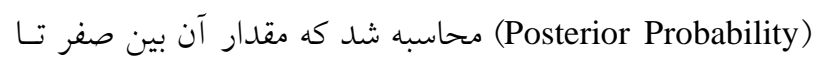

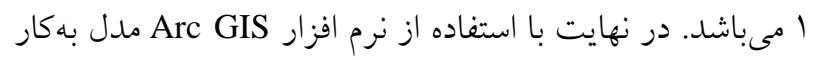

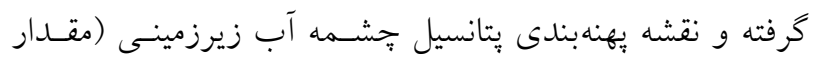
صفر تا يك) استخراج شد.

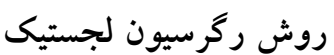

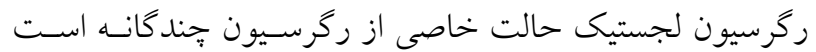

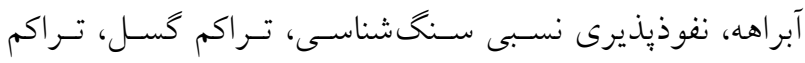

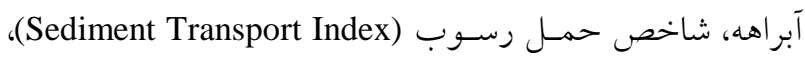

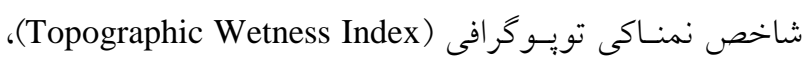

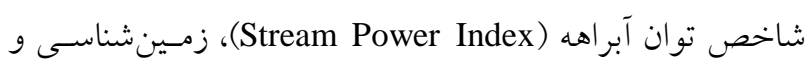
بارش در محيط سامانه اطلاعات جغر افيايى تهيه، كلاسهبنـدى و

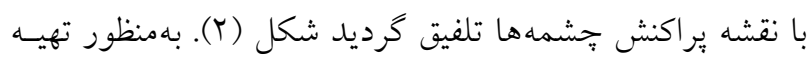

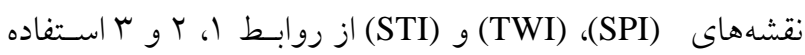
شد. نقشـهـ يوشـش و كـاربرى ارضسى نيـز از تصـوير مـاهواره

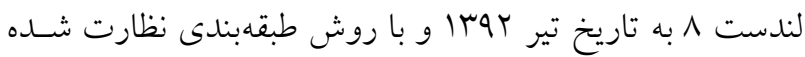
و استفاده از نمونههاى تعليمى تهيه كرديد.

$\mathrm{SPI}=\mathrm{A}_{\mathrm{s}} \times \tan (\beta)$

TWI $=\ln \left(\mathrm{A}_{\mathrm{s}} / \tan (\beta)\right)$

$\operatorname{STI}=\left(\frac{A_{s}}{r / / r}\right)^{d / 9}\left(\frac{\operatorname{Sin}(b)}{\sigma / \wedge \wedge 99}\right)^{r / r}$

كه در آن: As: مساحت ويزه بالادست يك بيكسل (مترمربع بـر متر) و $\beta$ شيب ييكسل (راديان) مىباشد.

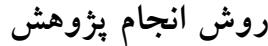

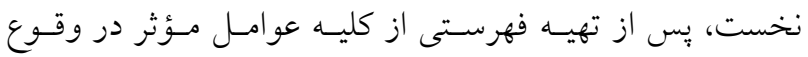

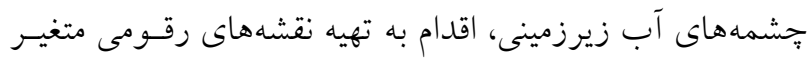

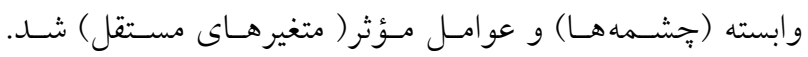

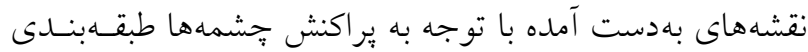

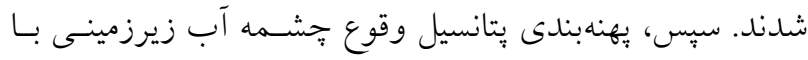

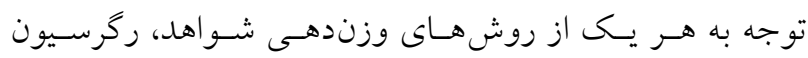

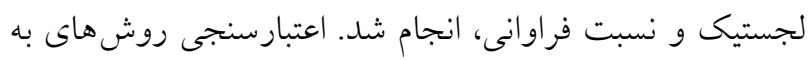

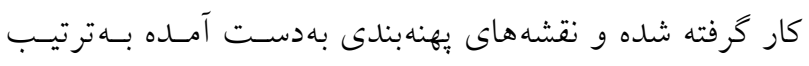
توسط منحنسى ROC (Relative Operative Curve) و نمهـودار

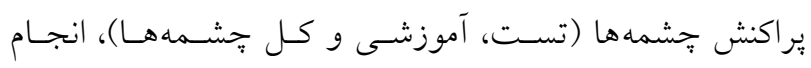

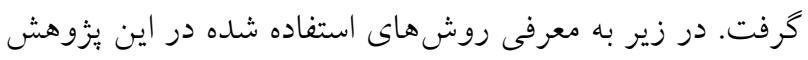
مبرداخته مىشود.

روش وزندهى شواهد (Weight of Evidence) روش وزندهى شواهد بر تئسورى بيـزين در احتمـالات شـرطى ورسى 

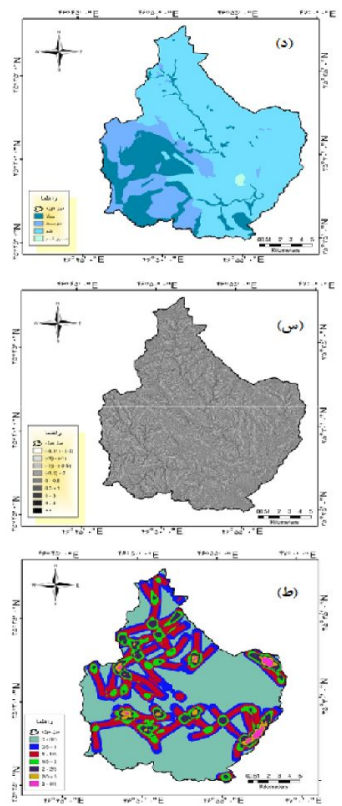
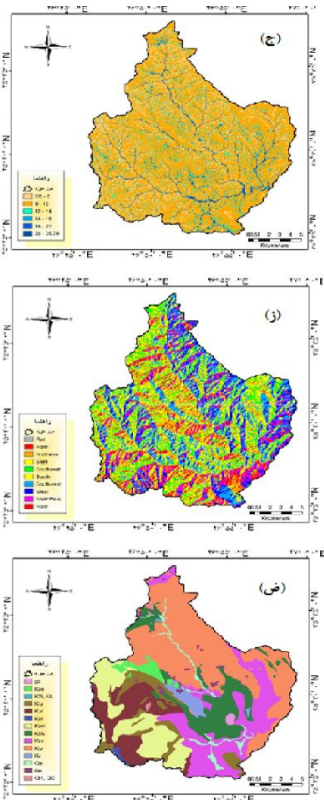
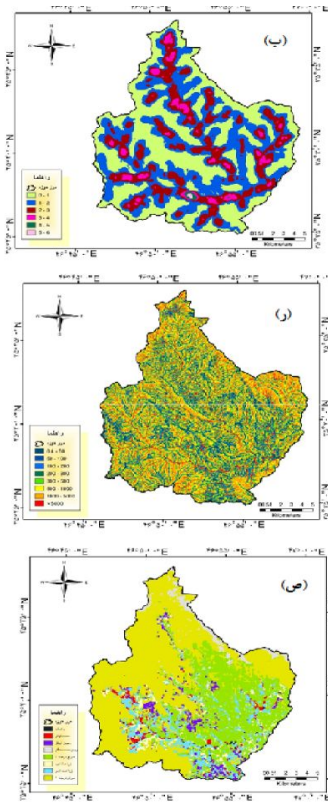
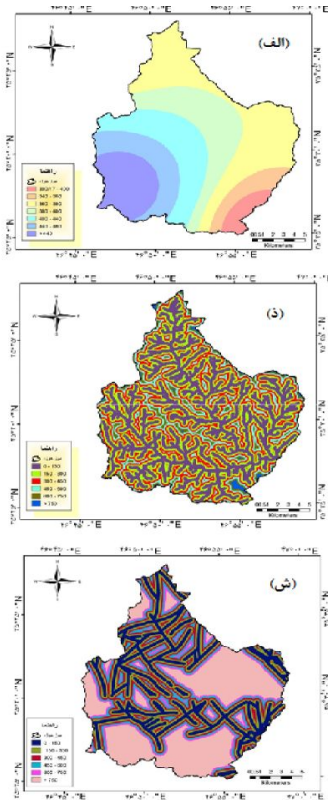

شكل r. نقشه برخى عوامل مؤثر در وقوع جشمههاى منطقه مورد مطالعه: الف) نقشه بارندگى، ب) تراكم آبراههها، ج) شاخص نمناكى

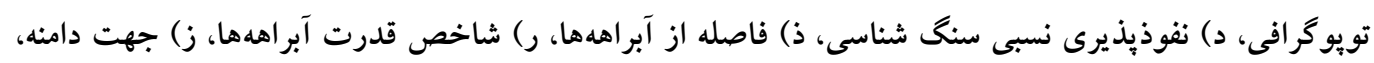

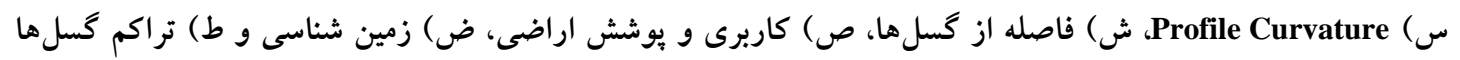

متغير باينرى (صفر يا ا ) تعريف شود و مقـدار آن يـك باشــد، بدينمعنى است كه جشمه وجود داشته (احتمال معـادل يـكى) و اخر مقدار آن صفر باشد، بـر عـدم وجـود جشهمه (احتمـال معادل صفر ) دلالت دارد.

$$
\text { روش نسبت فراوانى }
$$

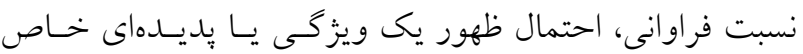

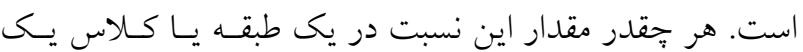

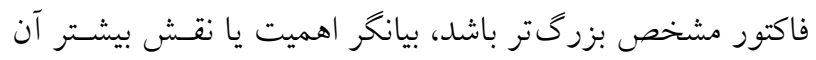

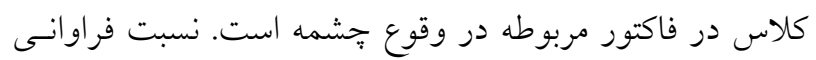

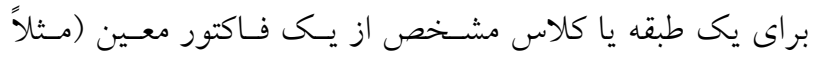
شيب) از رابطه زير قابل محاسبه است: $\mathrm{FR}=\frac{\mathrm{A}}{\mathrm{B}} / \frac{\mathrm{C}}{\mathrm{D}}$

كه A تعداد جشمهها در كـلاس مـورد نظـر، B تعـداد كـل جشمه هاى موجود در منطقه، C تعداد بيكسل هاى كلاس مـورد نظر، D تعداد كل بيكسل هاى مربوط بـهـ فــاكتور مربوطـهـ (مـثلاً شيب) مىباشد.
كه در آن متغير وابسته، كسسته بوده و تنها دو مقدار ممكن • و و 1 را مى تواند بهخود اختصاص دهد. كاربرد رگرسيون لجستيك،

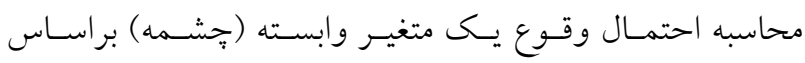

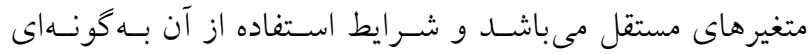

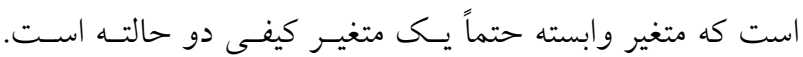
شكل كلى مدل ركرسيون لجستيك بهصورت زير است: $\mathrm{Y}=\mathrm{a}+\mathrm{b}_{1} \mathrm{x}_{1}+\mathrm{b}_{\mathrm{r}} \mathrm{x}_{\mathrm{r}}+\ldots+\mathrm{b}_{\mathrm{n}} \mathrm{x}_{\mathrm{n}}$

كه Y متغير وابسته و Xi متغير مستقل مىباشــند. ضـرايب

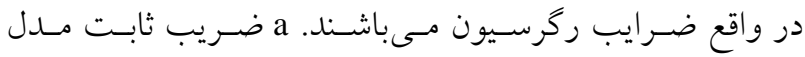

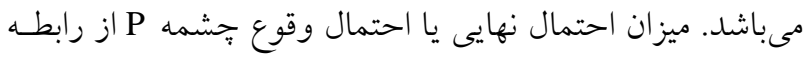
زير بهدست مى آيد:1

$\operatorname{GSP}_{\mathrm{LR}}=\mathrm{P}=\frac{\mathrm{e}^{\mathrm{Y}}}{1+\mathrm{e}^{\mathrm{Y}}}$

مزيت ركرسيون لجستيك نسبت به سـاير ركرسيونهـايى كه ضرايب مدل را با روش حداقل مربعات بهدست مسى آورنـــ اين است كـه لزومسى بــراى وجـود رابطـه خطى ميـان متغيــر

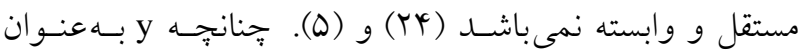


جدول ا. ضرايب وزندهى شواهد و نسبت فراوانى تعدادى از عوامل مؤثر بر ظهور جشمه

\begin{tabular}{|c|c|c|c|c|c|c|}
\hline FR & $\mathrm{P}$ & $\mathrm{C}$ & $\mathrm{W}+$ & تعداد جشمهها & تعداد بييكسل & فاكتورها \\
\hline & & & & & & شيب (درجه) \\
\hline $1 / 4 V_{0}$ & ./००/Or & $0 / 4 Y \wedge$ & $\circ / \mu \wedge V$ & $11 \mathrm{~V}$ & V9099 & $\circ-0$ \\
\hline $1 / 099$ &.$/ 00194$ & ०/QTI & $0 / 40$ & IMt & NTMG & $0-10$ \\
\hline סחואו & $0 / 00149$ & $\circ / T V \Delta$ & $0 / \pi q$ & $1 \Lambda t$ & ITTONG & $10-10$ \\
\hline -/ATG & ००००^ৎ & -0/TrG & $-0 / 119$ & $\mid r \Lambda$ & $149.1 \mathrm{~V}$ & $10-r_{0}$ \\
\hline ०/VN & \%०००VGA & $-0 / T \Delta q$ & $-0 / 019$ & 91 & ITVGDG & $r_{0}-r_{0}$ \\
\hline$\circ / \mu \wedge$ & .1000490 & $-1 / 04$ & $-0 / 990$ & ro & $\vee \Delta \wedge \wedge \Delta$ & $r \Delta-r_{0}$ \\
\hline$\circ / \Delta V_{0}$ & ००००0qR & $-\circ / 0 \wedge \circ$ & $-0 / 091$ & 11 & rorNT & $\mu_{0}-r \Delta$ \\
\hline.$/ 111$ & 0100119 & $-Y / T \circ r$ & $-T / 19 T$ & 1 & NGY。 & $r \omega-r \phi$ \\
\hline \multirow[t]{2}{*}{$\circ$} & $0 / 00104 q$ & $-1 \circ \circ \circ 0$ & $\circ$ & 。 & Mls & $Y D_{-} G Y / T$ \\
\hline & & & & & & نفوذيذيرى \\
\hline $1 / 9 V \wedge$ & $\circ / 0 \circ Y \circ 091$ & $\circ / 90$ & $0 / 9 \wedge Y$ & rVQ & Irrsta & فاقدنفوذيذيرى \\
\hline $0 / 191$ & \%०००QMru & $-0 / 1 Y$ & $-\circ / 1 \circ V$ & $1 \circ \wedge$ & $110 \wedge 11$ & نفوذيذيرى كم \\
\hline$\circ / N \mu_{0}$ & $\circ \circ \circ \circ \vee \Delta \wedge \Delta$ & $0 / 99$ & $-0 / \mu / 4$ & TTV & FTIEYI & نفوذيذيرى متوسط \\
\hline \multirow[t]{2}{*}{ 。 } & $0 / 00104 q$ & - \%/०० & $\%$ & $\circ$ & rYAq & تفوذ يذيرى بالا \\
\hline & & & & & & جهت دامنه \\
\hline I/rTV & ०/००|rN| & $0 / 799$ & $0 / T \wedge F$ & ro & $r q 011$ & $(-1)-0$ \\
\hline $1 / \pi r 4$ & o/00/r & $0 /$ TqV & $0 /$ TAr & щ & TVOVG & $\circ-Y Y / Q$ \\
\hline I/ITV & ०००IrA & $0 / Y q V$ & $0 /|Y|$ & 94 & NOYYG & $Y Y / D-9 V / D$ \\
\hline OIGKY & $.0011 \mathrm{Vr}$ & $0 / / \mu \wedge$ & $-0 / 4 y$ & 90 & $q \vee r v q$ & $9 V / D-11 T / 0$ \\
\hline.$/ 914$ & 01000991 & $-0 / 499$ & $-0 / 019$ & 19 & $q \mu \wedge \cdot \Lambda$ & $11 r / 0-10 V / 0$ \\
\hline $1 / 091$ & .100090 & $-0 / 10 \mu$ & $\circ / \circ \wedge \Lambda$ & $1 \circ V$ & qkrVo & $10 V / D-Y \circ Y / \Delta$ \\
\hline $1 / 1 \circ \wedge$ & ه & $\circ / 1 \circ r$ & $0 / 1 \circ 4$ & $1 r_{0}$ & $104 Y 09$ & $r \circ r / D-Y Y V / D$ \\
\hline$\circ / \Lambda V^{F}$ & od/1/R & (1/ & rm & $9 V$ & VMVIT & $r Y V / D-Y Q Y / D$ \\
\hline.$/ 9 V Y$ & . & $-0 / 1 F V$ & -O/OYG & $\Delta \wedge$ & oVTVV & $r q r / D-r r V / D$ \\
\hline $1 / 199$ & $0 / 00091$ & $-0 / 0{ }^{\prime} \Lambda$ & $\circ / \wedge \mu$ & Mt & ro\&99 & $M T V / D-r G 0$ \\
\hline
\end{tabular}

$$
\mathrm{GSPI}_{\mathrm{FR}}=\sum_{\mathrm{i}=1}^{\mathrm{m}} \mathrm{FR}_{\mathrm{i}} ;(\mathrm{i}=1, \mathrm{r}, \ldots, \mathrm{m})
$$

نتايج

\section{نقشه عوامل مؤثر بر وقوع جشمهها}

شكل شماره r، نقشههاى تهيه شده تعدادى از عوامـل مـؤثر در
براى بهدست آوردن شـاخص يتانسـيل ظهـور جشـمه آب

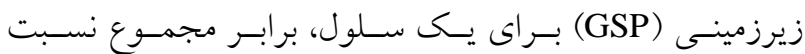

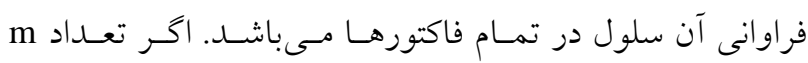

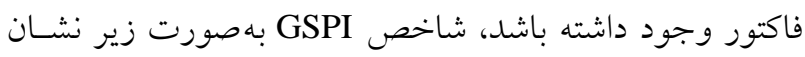
داده مىشود. 
جدول Y. متغيرهاى باقيمانده در مدل رگرسيون لجستيك و ضرايب آنها در گام دوازدهم

\begin{tabular}{|c|c|c|c|c|c|c|}
\hline $\operatorname{Exp}(B)$ & Sig. & Df & Wald & S.E & $\mathrm{B}$ & متغيرهاى مستقل \\
\hline$\circ / \wedge \wedge \Delta$ & $\circ$ & 1 & $\| M / \Lambda \mid t$ & $0 / 011$ & $-0 / 1 T r$ & درجه شيب \\
\hline I/TMY & $0 / 0+1$ & 1 & $4 / 190$ & $\circ / 1 \circ 4$ & $\circ / Y 1 \circ$ & شكل شيب \\
\hline$\circ / \vee \wedge \Delta$ & $\circ$ & 1 & $\mid Y Y / \circ \Delta Y$ & $0 / 0 Y T$ & - O/TKM & زمينشناسى \\
\hline$\circ / 4 \mid V$ & $\circ$ & 1 & $19 / 40 V$ & $0 / 419$ & $-\circ / \wedge V Q$ & Plan curvature \\
\hline I/IM & $\circ$ & 1 & IV/YGK & ००MI & $0 / 1 r q$ & جهت دامنه \\
\hline.$/ 99 V$ & $\circ$ & 1 & $0 . / 114$ & $\circ / 0 \circ 0$ & -o/०० & فاصله از آبراهه \\
\hline $0 / 994$ & $\circ$ & 1 & $\vee Q / Y \wedge \uparrow$ & $0 \% 49$ & $-0 / 4 \varphi_{0}$ & كاربرى/يوشش اراضى \\
\hline $1 / 000$ & $\circ / \circ \circ \Delta$ & 1 & V/AVQ & $\circ / 0 \circ$ & $-0 / 490$ & شاخص قدرت آبراهه \\
\hline 1/o०r & $\circ$ & 1 & D DT/KI & $\circ / 0 \circ Y$ & $\circ / 0 \circ \wedge$ & شاخص حمل رسوب \\
\hline
\end{tabular}

بين هجده فاكتور بهدليل معنى دار بودن از لحاظ آمارى در سطح آمارى هو درصد، شناخته شد. در اين مرحله يسس از اسـتخراج دادهها از لايههاى اطلاعاتى (فاكتورهاى مستقل)، ضرايب معادله احتمال وقوع جُشمه براسـاس همبسـتخى متغيرهـاى مستقل و

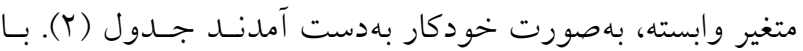
توجه به اين ضرايب، معادله لا به شكل زير بهدست آمد:

$$
\begin{aligned}
& \mathrm{Y}=0 / Y Y 4+0 / / Y T(\mathrm{~S})+0 / T I(\mathrm{C}) \\
& -\circ / \wedge \vee(\mathrm{PLC})-. / \mathrm{TY}(\mathrm{G})+\circ / \operatorname{Tr}(\mathrm{A}) \\
& -\circ / 4 r(\mathrm{~L})-\circ / \circ \circ \mathrm{SD})-\circ / 490 \text { (SPI) } \\
& +\circ / \circ \circ \wedge(\mathrm{STI})
\end{aligned}
$$

$\operatorname{GSP}_{\mathrm{LR}}=\frac{\mathrm{e}^{\mathrm{Y}}}{1+\mathrm{e}^{\mathrm{Y}}}$

با قرار دادن Y در رابطه ها معادلـه نهـايى كـه همـان احتمـال وقوع جشمه با روش رگرسيون لجستيك مىباشـــ بـهدسـت آمــد. كه: LRP احتمال وقوع جشــمه در حـوزه آبخيـز جهـل خـزى و دامنه آن بين صفر تا يك مىباشد. شكل (T)، S : درجـه شـيب، C:

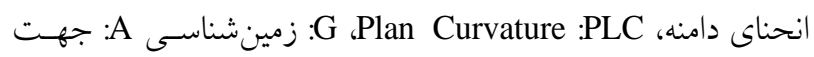
دامنه، L: كاربرى اراضى / يوشـش اراضسى، SD: فاصـله از آبراهـه، :SPI

جدول متغيرهاى مدل رگرسيونى (Variable in the Equation جإ

(Table

جدول شـماره r يكسى از مهـمتـرين خروجسىهـاى رگرسـيون
ايجاد جشمهه ها را نشان مى دهل. بهطور مثال نقشه جهــت دامنـه

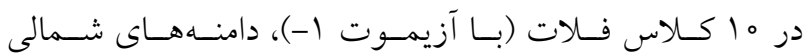

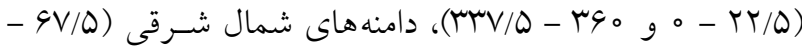

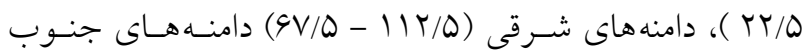

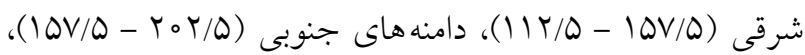

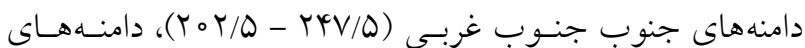

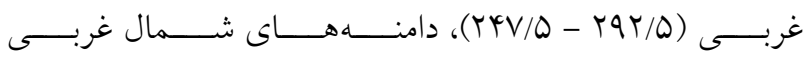

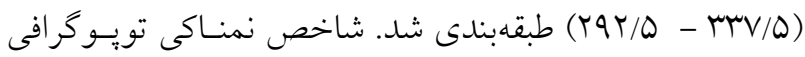
د) نفوذيذيرى نسـبى سـنخششناسـى ذ) فاصـله از آبراهـهـــا ر)

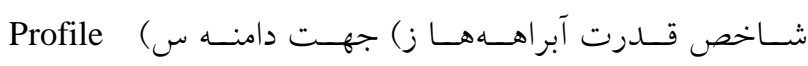

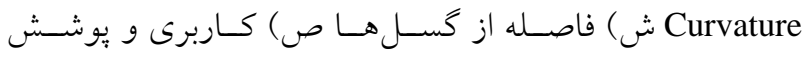
اراضى ض) زمينشناسى ط) تر اكم گسل ها با هميوشـانى نقشـهـ

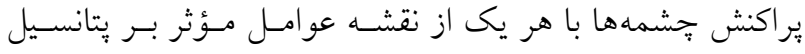
وقوع جشمه ها، ضرايب مربوط به روش هاى نسـبت فراوانسى و وزندهى شواهد طبق جدول ( ) بهدست آمد. بهنه بندى يتانسيل ظهور جشمه آب زيرزمينى بـا اسـتفاده از روش رگرسيون لجستيك

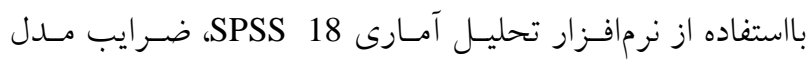
تخمين زده شد. يس از انجام آناليزهاى رگرسيونى لجستيك گام

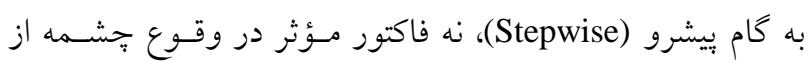




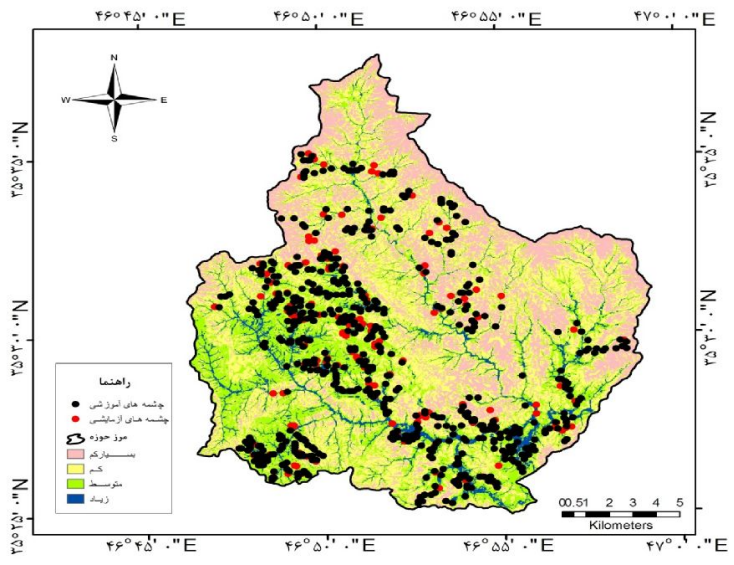

شكل f. نقشه يتانسيل جشمه آب زيرزمينى با روش نسبت فراوانى (GSP

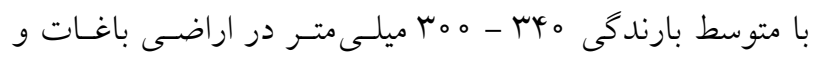

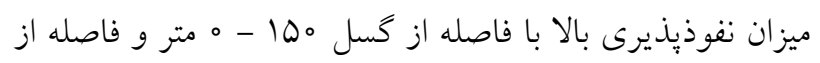

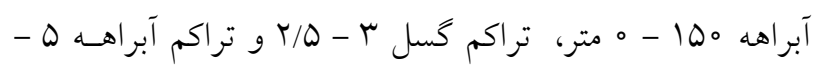
† كيلومتر در واحد سطح (كيلومترمربع) و انحناى مقعـر، بـالاتر بوده و بهاين معنى است كه در حوضسه مـورد مطالعسه يتانسـيل ظهور جشــمه در طبقـات و شـرايط ذكـر شـده بـالاتر از سـاير طبقات مىباشد. با اعمال ضرايب نسبت فراوانى استخراج شـده از جدول شماره ( (1) به متغيرهاى مستقل، نقشـه يهنـهبنـدى بـه

روش نسبت فراوانى بهدست آمد شكل (Y).

صحت سنجى روشهاى WOE

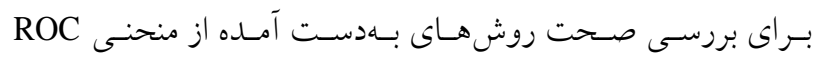
استفاده شد. قابليت بيشبينى مدل توسط سطح زيـر منحنى (AUC)

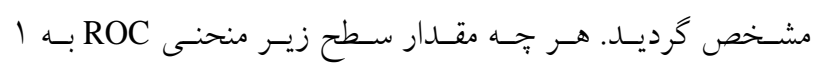

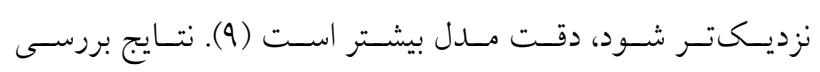
صستستسنجى روشهــاى FR، و LR ، WOE در شـكل شـماره ه نمايان است. نتايج نشان مىدهد كه هر سه مدل بهدليل مقـدار سـطح زير منحنى بالاتر از V9 درصد از صحت بالايى برخوردار هستند. با توجه به جدول (r) مقدار سطح زير منحنى براى روشهـاى

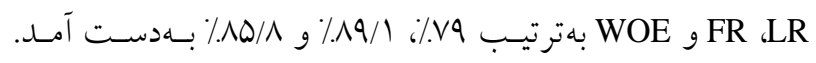
براساس مقدار سطح زير منحنى و خطاى استاندارد، صـحت نقشـه

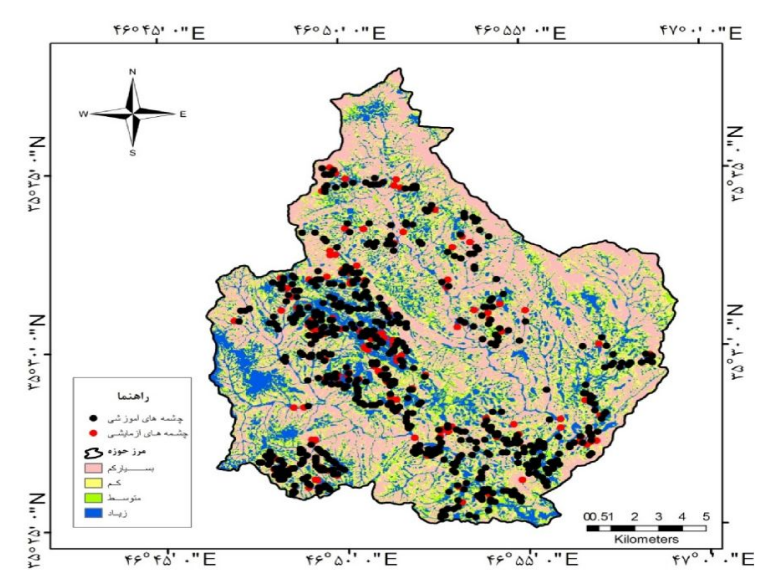

شكل r. نقشه يتانسيل جشمه آب زيرزمينى با روش رگرسيون لجستيك(GSP LR)

لجسـيكى مسىباشـــ جـــرا كـه ضـرايب معادلـه (B) Y)، خطـاى

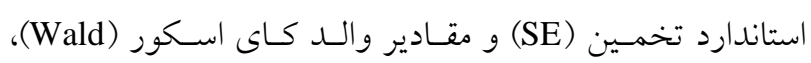
درجه آزادى (df)، معنى دارى آمارى در سطح ه9 درصــ (Sig)، لكاريتم طبيعى ضريب ركرسيونى (Bxp(B))، را نشان مى دهـــ. در اولين ستون اطلاعات، ضرايب نهايى مدل بعد از rا مرحلـه تكرار مدل نشان داده شده است جدول (Y). يس از برآورد ضرايب (B) براى هر يك از متغيرهـاى مسـتقل، با ضرب نمودن اين ضرايب در هر متغير مستقل نقشـهـ يتانسـيل

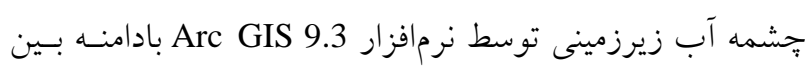
صفر تا يك بهدست آمد شكل (r). بهنه بندى يتانسيل ظهور جشمه آب زيرزمينى بـا اسـتفاده از روش نسبت فراوانى

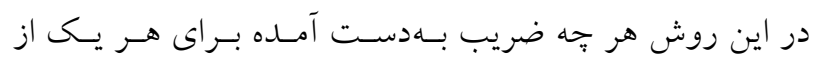
طبقات يك عامل بيشتر از يك باشد، نشانه تأثير بيشتر آن طبقـه

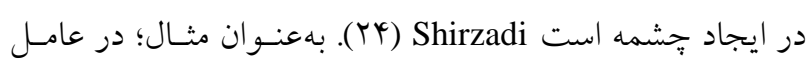
درجه شيب طبق جدول (1) مقـدار نسـبت فراوانسى در طبقـات اول تا سوم يعنى از شيب صـفر تـا ها درجـهـ بيشـتر از ا و در

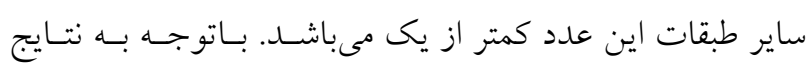
بهدست آمــده ضـريب نسـبت فراوانى، در شـيبهـاى ه 1 - ه ه

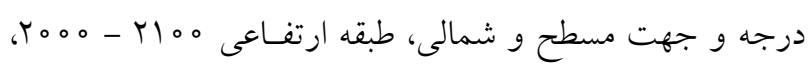




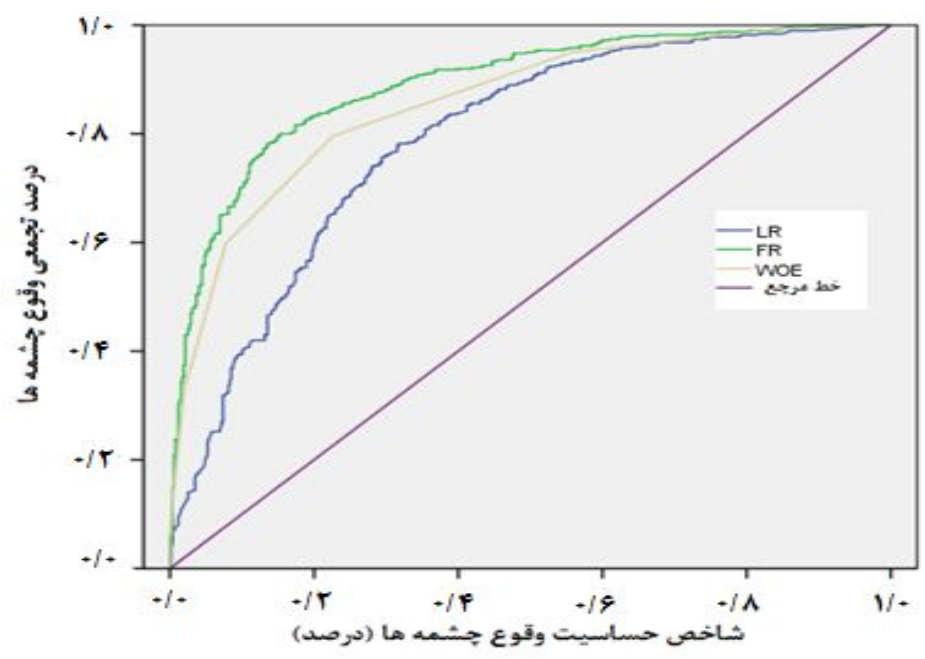

شكل ه. ارزيابى صحت روشهاى LR و FR و WOE با استفاده از منحنى ROC

جدول r. خطاى استاندارد و سطح زير منحنى ROC نقشه هاى GSP حوزه جهل

\begin{tabular}{|c|c|c|}
\hline خطاى استاندارد & سطح زير منحنى & مدل مورد استفاده \\
\hline $0 / 014$ & $\circ / \sqrt{ } 9$ & ركرسيون لجستيك \\
\hline $0 / 010$ & $\circ / 19$ & نسبت فراوانى \\
\hline $0 / 014$ & $\%$ \%৯/^ & روش وزندهى شواهد \\
\hline
\end{tabular}
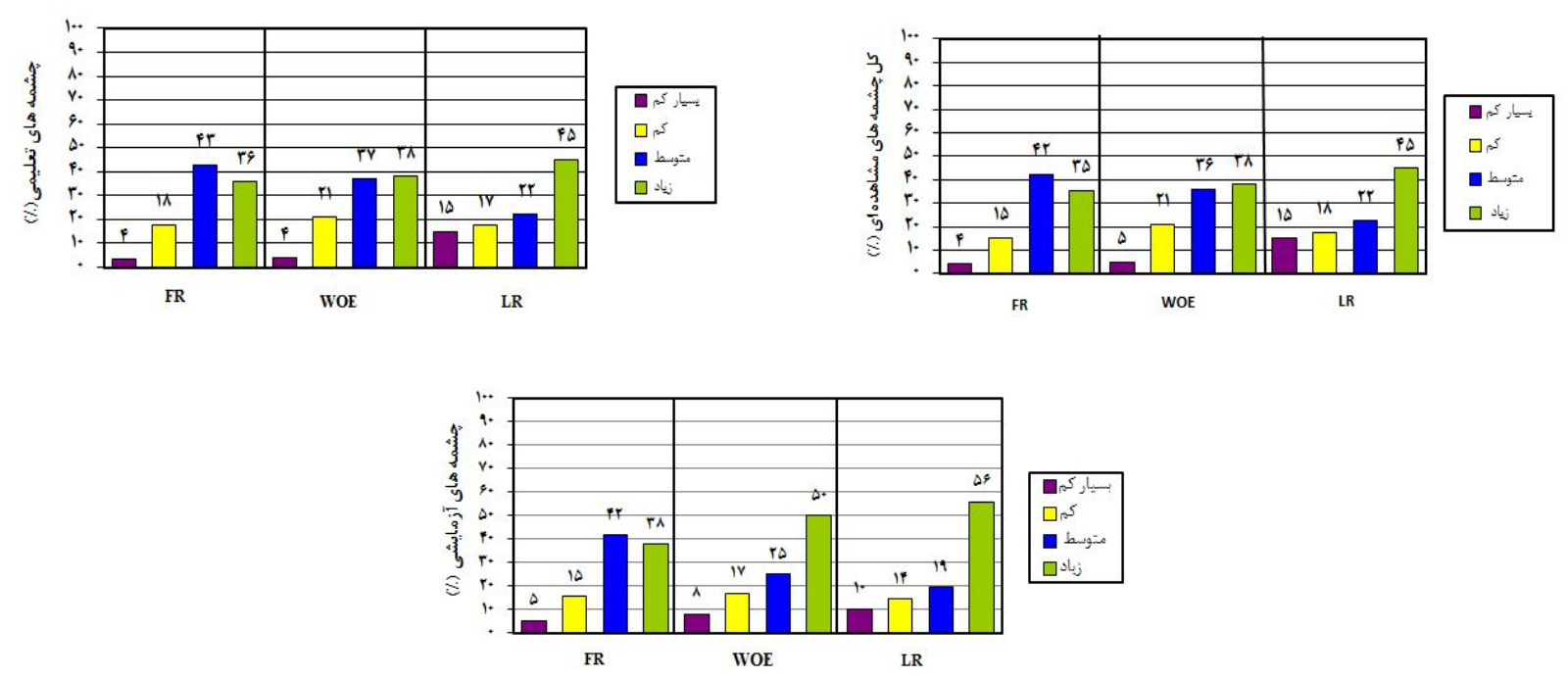

شكل 9. بررسى صحت نقشههاى بهنهبندى(GSP) براساس بر اكنش جشمهها در حوزه آبخيز جها گزى

بهنهبندى بهدست آمده با روش نسبت فراوانى نسـبت بـه دو روش اعتبارسنجى نقشههاى بهنهبندى يتانسيل جشمه آب زيرزمينى با روشهاى WOE ديخر در منطقه مورد مطالعه، تأييد گرديد.

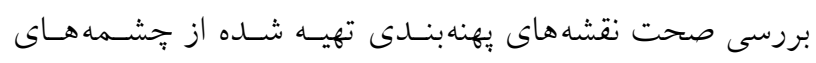




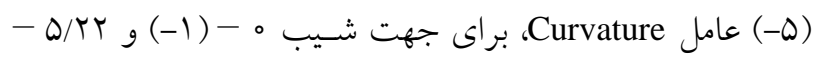

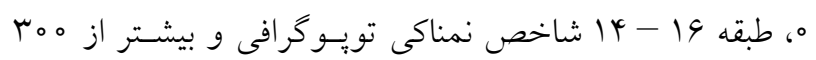

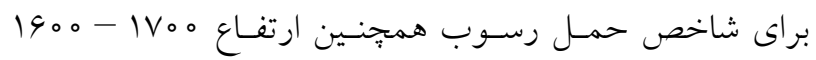
بيشترين احتمال وقوع جشمه آب زيرزمينى را دارنـــ. در روش ركرسيون لجستيك در اولين مرحله هر متغيرى كه داراى سـطح معنى دارى كمتر از مقدار مشخصى شود (هـ/ه در سطح اعتمـاد

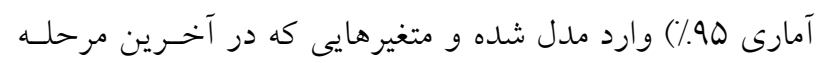

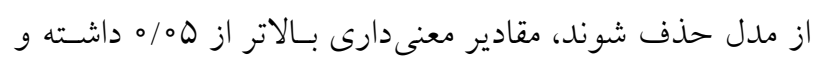
از مدل حذف مىشوند. بنابراين، در مدل بهدست آمـده در ايسن يزوهش، 9 عامل از IV عامل در روند بررسى باقى مانده و بقيـه از مدل حذف شــند. فاكتورهـاى انتخـاب شـده توسـط مــل ركرسـيون لجسـتيك عبارتنـــ از: درجـه شـيب، شـكل شـيب، زمينشناسى، Plan Curvature، جهت شيب، فاصسله از آبراهـه، كاربرى اراضى / بوشش اراضى، شاخص قدرت آبراهه، شاخص ،

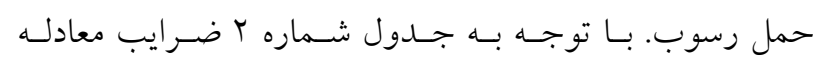
ركرسيون لجستيك بعد از با مرحله اجراى مـدل، نهـايى شـد. ضريب مثبت (B)، بيانكر آن است كه آن متغير در وقوع جشـمه نتـش بيشـترى دارد و بــالعكس ضـريب منفـى (B)، نمايسانخر

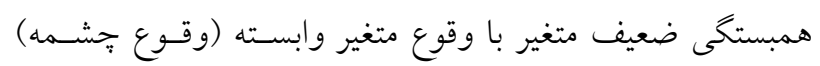
اسـت Ayalew (1). مقــار ضـريب منفـى ركرسـيون گويـاى مطلبى نيست، زيرا مقدار معنى دارى آمارى در سطح ه9 درصـد كه از آزمون والد بهدست آملدهاند در ستونى بهنام sig ارائه شده است و اين مقادير براى تمامى متغيرها كمتر از هـ/ مسىباشـند

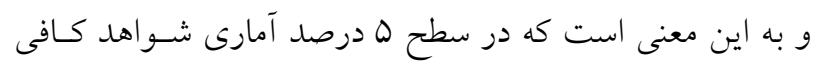

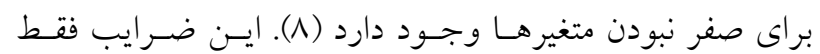

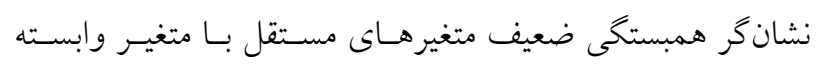

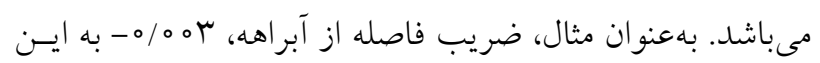
معناست كه با فرض ثابت ماندن ساير عوامـل، بـهازاى افـزايش يك واحد فاصله از آبراهه، بهمقدار لكاريتم شانس وقوع تجشمه،

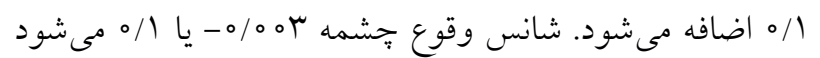
كه اين نشان دهنده تأثيرى جزئى است. در ايسن مطالعهـ عوامـل درجه شيب، زمينشناسـ، Plan Curvature، فاصسله از آبراهـه،
تعليمى (آموزشى)، آزمايشى و كل جشمههــا انجـام گرديــد. بـا

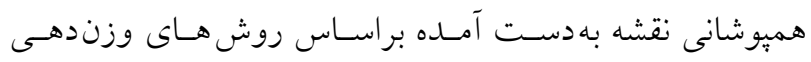
شواهد، رخرسيون لجستيك و نسبت فراوانى و موقعيـت مكـانى

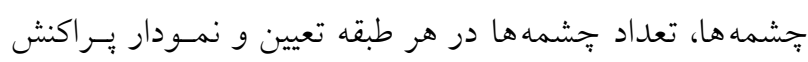
آنها تهيه شد (شكل 9). مشاهده شكل 9 نشان مى دهد، با توجـه

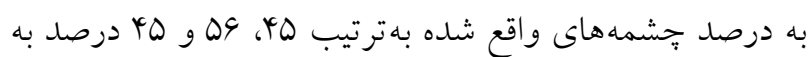

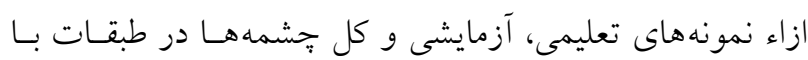
احتمال وقوع زياد، روش ركرسـيون لجسـتيك داراى بيشـترين صحت نسبت به دو روش ديخر مىباشد.

\section{بحث و نتيجه كيرى}

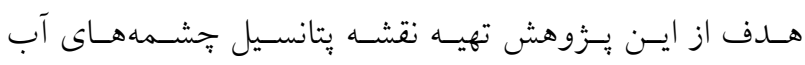

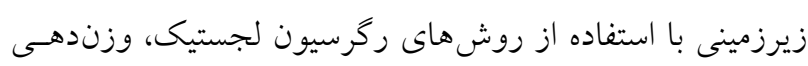
شواهد و نسبت فراوانى و مقايسه كارايى اين روش ها در حـوزه آبخيز جهرل گزى، استان كردستان مىباشد. از هفــده عامـل مـؤثر در ظهور جشمهه جا شامل: زمينشناسى، فاصـله از كسـل، تـراكم كسل، ارتفاع، نفوذيذيرى نسـبى سـنگ شناسـى، درصــ شـيب، Profile Curvature, Curvature, جهت شيب، نقشههاى انحنـا Plan Curvature) شاخص حمل رسوب، توان آبراهه، شاخص نمناكى تويو گرافى، يوشش /كاربرى ارضى استفاده شد. فاكتورهاى شـاخص نمنـاكى

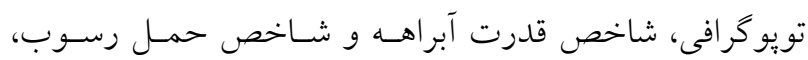
ميزان تأثير تويوگرافى بر روى توزيع مكـانى رطوبـت خـاى را

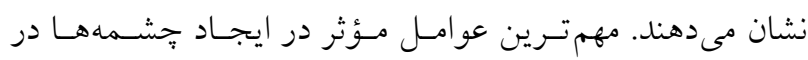

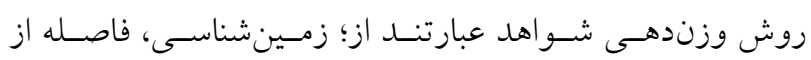

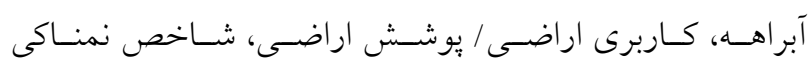
تويوكر افى، درجه شيب، شاخص حمل رسوب و شكل دامنه. با توجه به نتايج بهدسـت آمـده از ايسن روش، در طبقـه بـالاتر از

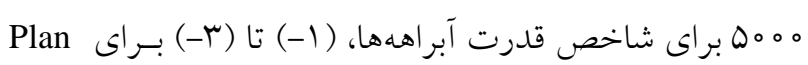
Curvature

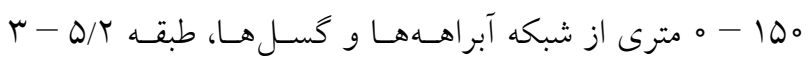

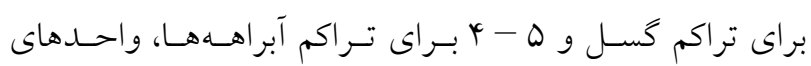

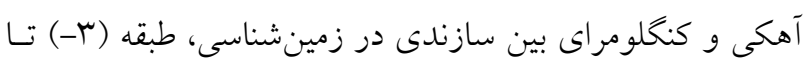


وقوع جشمه آب زيرزمينى مشاهده كُديد. در ارتبـاط بـا عامـل

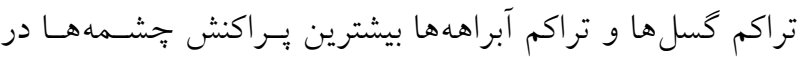

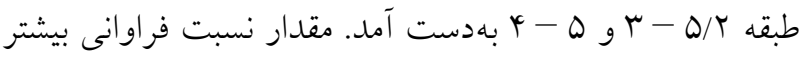
در عامل Profile Curvature، در طبقه ץ - ب و در كلاس بيشـتر

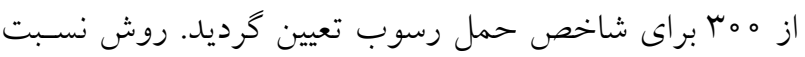

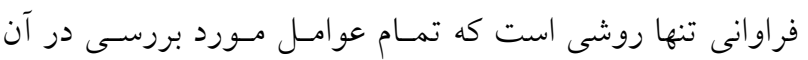

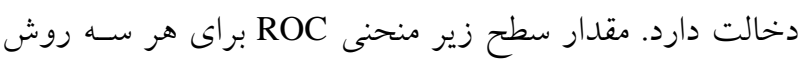

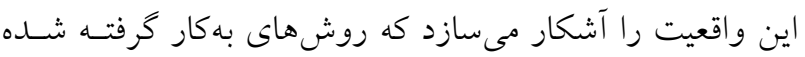

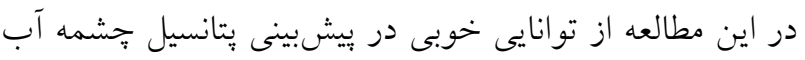
زيرزمينى برخوردار بوده و در اين ميان روش نسبت فراوانى بـا لـا

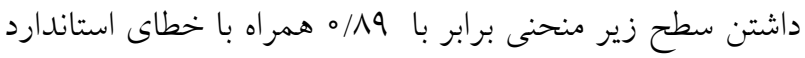

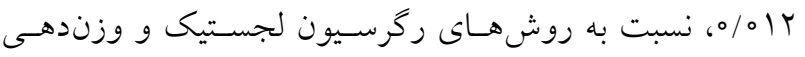

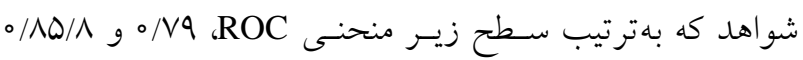

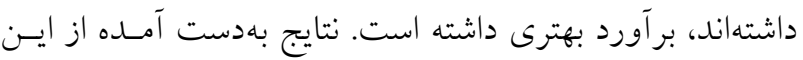

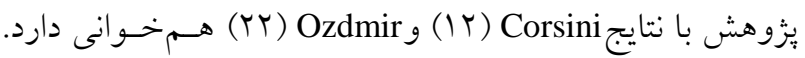

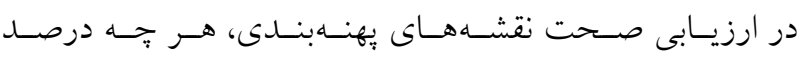
جشمه هاى واقع در طبقات بالاتر نقشه يتانسيل تهيه شده بيشتر

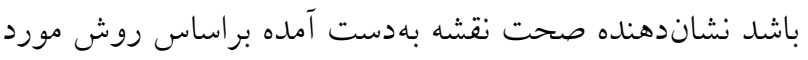

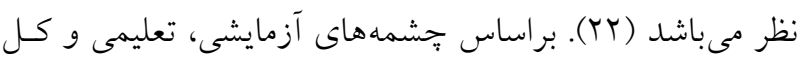

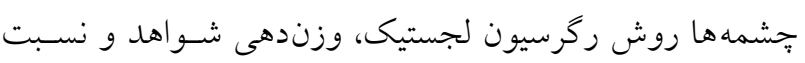

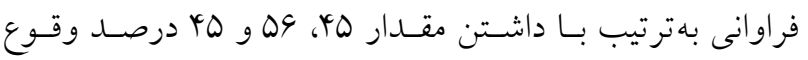

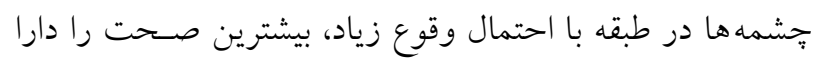

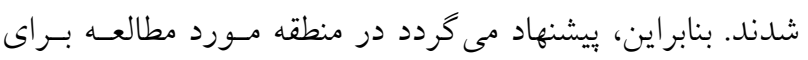

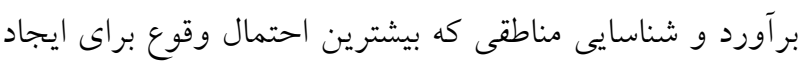

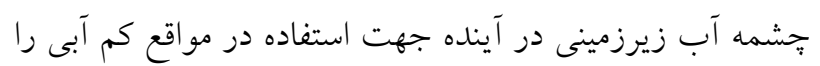

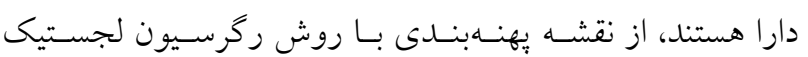

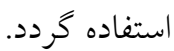

شاخص قدرت آبراهه و كاربرى ارضى / يوشش ارضسى ضـريب

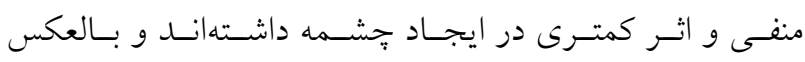

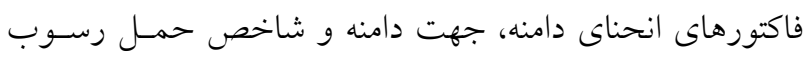

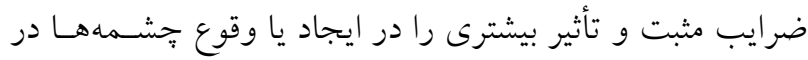

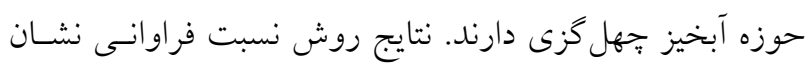

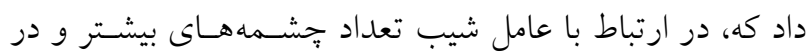

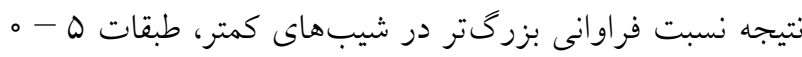

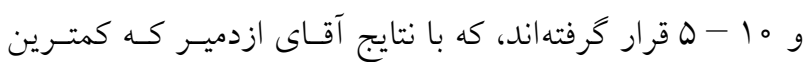
وقوع جشمه را در شيب ه ا درجه و بـالعكس بيشـترين وقـوع

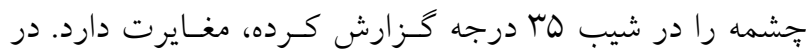

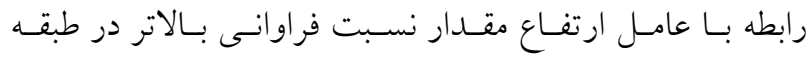

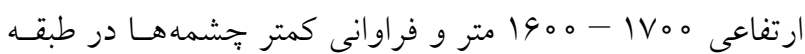

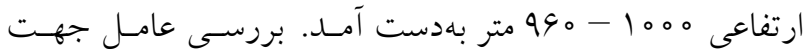
شيب نشان داد بيشترين بر اكنش جشمهها در حوزه مورد مطالعه در جهت هاى شمالى و مسطح قـرار داشـت. بـا بررسى عامـل

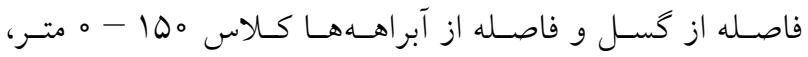
بيشترين مقدار نسبت فراوانى را بهخود اختصاص دادند. ارتبـاط

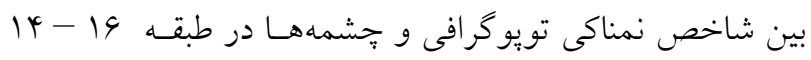

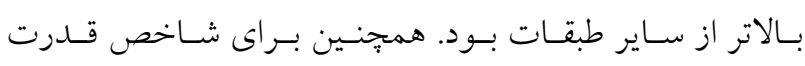

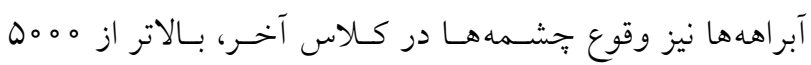
بيشترين مقدار را به خود اختصاص داد. در عامل انحناى شسيب

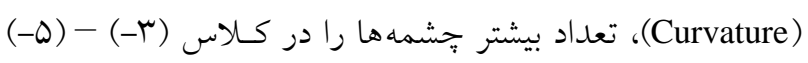

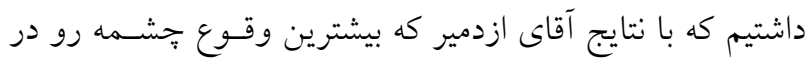

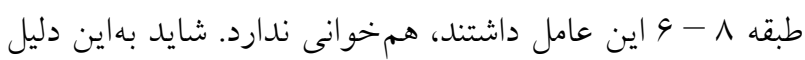

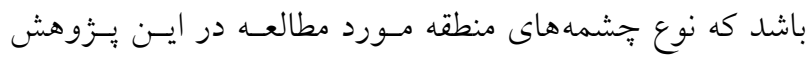

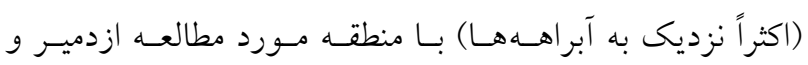

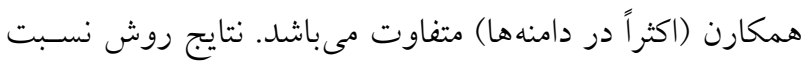

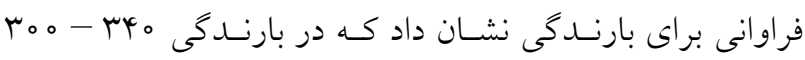

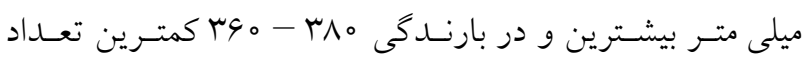

منابع مورد استفاده

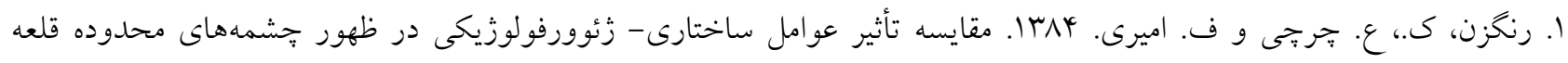




$$
\begin{aligned}
& \text { رزه- بيدروبه با محدوده تاقديس يابده در شمالغرب و شمالشرق خوزستان. مجموعه مقالات نهمين همايش انجمن زمينشناسى } \\
& \text { ايران. دانشخاه تربيت معلم تهران، } \\
& \text { r. سليمانى، ك.، س. زندى و ج. زندى. rوبا. تهيه نقشه يتانسيل وقوع جشمههاى آب زيرزمينى با استفاده از روشهاى آمارى }
\end{aligned}
$$

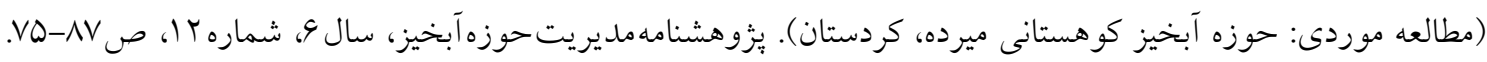

$$
\begin{aligned}
& \text { س. سيف، ع و ا. كارگر. هوبا. يتانسيليابى منابع آب زيرزمينى با استفاده از روش تحليل سلسله مراتبى و سيستم جغر افيايى، مطالعه }
\end{aligned}
$$

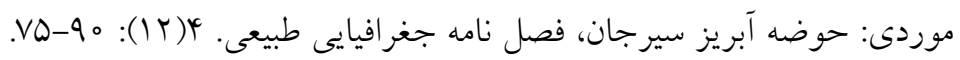

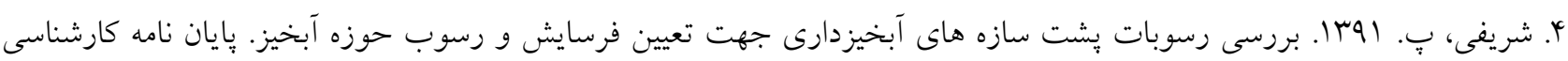

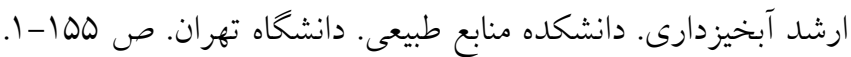

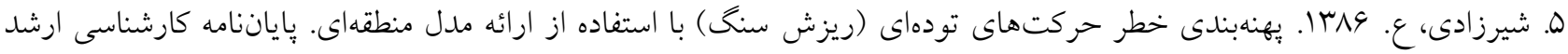

$$
\begin{aligned}
& \text { آبخيزدارى. دانشكده منابع طبيعى. دانشخاه مازندران (دانشخاه علوم كشاورزى و منابع طبيعى سارى)، هما ص. }
\end{aligned}
$$

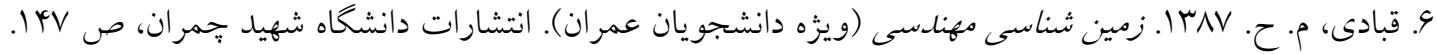

$$
\begin{aligned}
& \text { V. كلانترى، ن.، ع. خوبيارى و م. ص. درانى نزاد. اوسا. بررسى نقش شكستكى ها در آبدهى جُشمه جم آسياب در شمالشرق استان } \\
& \text { خوزستان. فصلنامه زمينشناسى كاربردى. A( (1): }
\end{aligned}
$$

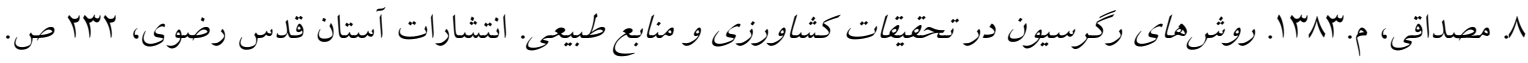

9. Akgun, A., E. A. H. A. Sezar, C. Nefeslioglu, B. Gokceoglu and B. Pradhan. 2012. An easy-to-use MATLAB program (MamLand) for the assessment of landslide susceptibility using a Mamdani fuzzy algorithm. Computer \& Geosciences. 38: 23-34.

10. Ayalew, L., H. Ymagishi, H. Marui and T Kanno. 2005. GIS-based susceptibility mapping with comparisons of result from methods and verifications. Engineering Geology. 81: 432-445.

11. Chowdhury, A., M. K. Jha, V. M. Chowdary and B. C. Mal. 2009. Integrated remote sensing and GIS-based approach for assessing groundwater potential in West Medinipur district, West Bengal, India. Int. J. Remote Sens. 30: 231-250.

12. Corsini, A., F. Cervi and F. Ronchetti. 2009. Weight of evidence and artificial neural networks for potential groundwater spring mapping: an application to the Mt. Modino area (Northern Apennines, Italy). Geomorphology 111: 79-87.

13. Dar, I., K. Sankar and M. Dar. 2010. Remote sensing technology and geographic information system modeling: An integrated approach towards the mapping of groundwater potential zones in Hardrock terrain, Mamundiyar basin. J. of Hydrology 394: 285-295.

14. Ganapuram, S., G. T. Vijaya Kumar, I. V. Murali Krishna, E. Kahya and M. C. Demirel. 2009. Mapping of groundwater potential zones in the Musi basin using remote sensing data and GIS. Adv. Eng. Softw. 40: 506-518.

15. Ghosh, S and E. J. M. Carranza. 2010. Spatial analysis of mutual fault/fracture and slope controls on rock sliding in Darjeeling Himalaya, India. Geomorphology 122: 1- 24.

16. Gogu, R. C., G. Carabin, V. Hallet, V. Peters and A. Dassargues. 2001. GIS based hydrogeological databases and groundwater modeling. J. Hydrogeol. 9(6): 555-569.

17. Jaiswal, R. K., S. Mukherjee, J. Krishnamurthy and R. Saxena. 2003. Role of remote sensing and GIS techniques for generation of groundwater prospect zones towards rural development - an approach. Int. J. Remote Sens. 24(5): 993-1008.

18. Madan, K. Jha., Y. Kamii and K. Chikamori. 2008. Cost-effective Approaches for sustainable Groundwater Management in Alluvial Aquifer Systems, DOI 10.1007/s11269-008-9272-6. Water Resoures Management. 23: 219-233.

19. Nobre, R. C. M., O. C. R. Filho, W. J. Mansur, M. M. M. Nobre and C. A. N. Cosenza. 2007. Groundwater vulnerability and risk mapping using GIS. modeling and a fuzzy logic tool. J. Contam. Hydrol. 94: $277-292$.

20. Oh, H. J., Y. S. Kim, J. K. Choi and S. Lee. 2011. GIS mapping of regional probabilistic groundwater potential in the area of Pohang City. Korea. J. Hydrol. 399: 158-172. 
21. Ozdemir, A. 2011a. Using a binary logistic regression method and GIS for evaluating and mapping the groundwater spring potential in the Sultan Mountains (Aksehir, Turkey). J. Hydrology 405(1-2): 123-136, Doi:10.1016/j.jhydrol.2011.05.015.

22. Ozdemir, A. 2011b. GIS-based groundwater spring potential mapping in the Sultan Mountains (Konya, Turkey) using frequency ratio, weights of evidence and logistic regression methods and their comparison. J. Hydrology 411: 290-308. doi:10.1016/j.jhydrol.2011.10.010

23. Prasad, R. K., N. C. Mondal, P. Banerjee, M. V. Nandakumar and V. S. Singh. 2008. Deciphering potential groundwater zone in hard rock through the application of GIS. Environ. Geol. 55: 467-475.

24. Shirzadi, A., L. Saro, Oh. Hyun-Joo and K. Chapi. 2012. A GIS-based logistic regression model in rock fall susceptibility mapping along a mountainous road: Salavat Abad case study, Kurdistan, Iran. Natural Hazard. 64: 1639-1656.

25. Solomon, S and F. Quiel. 2006. Groundwater study using remote sensing and Sørensen, R., Zinko, U., Seibert, J. 2005. On the calculation of the topographic wetness index: evaluation of different methods based on field observations. Hydrol. Earth Sys. Sci. Discuss. 2: 1807-1834.

26. Surrette, M., D. Allen and M. Journeay. 2008. Regional evaluation of hydraulic properties in variably fractured rock using a hydrostructural domain approach. Hydrogeol. J. 16(1): 11-30.

27. Tweed, S. O., M. Leblanc, J. A. Webb. and M. W. Lubczynski. 2007. Remote sensing and GIS for mapping groundwater recharge and discharge areas in salinity prone catchments, southeastern Australia. Hydrogeol. J. 15(1): 75-96. 


\title{
Comparing the Efficiency of Weight of Evidence, Logistic Regression and Frequency Ratio Methods for Mapping Groundwater Spring Potential in Ghelgazi Watershed, Kordestan Province of Iran
}

\author{
M. Erfanian ${ }^{1}$, H. Farajollahi ${ }^{1}$, M. Souri ${ }^{1}$ and A. Shirzadi ${ }^{*}$
}

(Received: March16-2015 ; Accepted : Dec. 6-2015)

\begin{abstract}
The aim of this study is to prepare the groundwater spring potential map using Weight of Evidence, logistic regression, and frequency ratio methods and comparing their efficiency in Chehlgazi watershed, province of Kurdistan. At first, 17 effective factors in springs occurrence including geology, distance to fault, fault density, elevation, relative permeability of lithological units, slope steepness, slope aspect, plan curvature, profile curvature, precipitation, distance to Stream, drainage Stream density, Sediment Transport Capacity Index (STCI), Stream Power Index, topographic wetness index (TWI) and land use/land cover (LU/LC) were selected. The validation processes of methods were conducted by relative performance characteristic curve (ROC). The area under an ROC curve (AUC) for the weight of evidence, logistic regression and frequency ratio was $85 / 8 \%, 79 \%$ and $89 \%$, respectively. The results showed that all methods are suitable estimator for mapping the groundwater spring potential in the study area. But the frequency ratio method with the most amounts is the best method to produce and map the groundwater spring potential. Also, validation of the mappings based on the percentage of pilot springs, training springs and all springs showed that the logistic regression, WoE and frequency ratio, with 45,56 and 45 percent of spring occurrence on the high potential classes respectively, had the highest validation.
\end{abstract}

Keywords: GSP, WoE, Logistic regression, Frequency ratio, ROC, Chelgazi watershed.

1. Dept. of Watershed Management Eng., College of Natural Resour., of Urmia, Urmia, Iran.

2. Dept .of Rangeland and Watershed Management Eng. College of Natural Resour., Univ. of of Kurdistan, Kurdistan, Iran

*: Corresponding Author, Email: A.shirzadi@uok.ac.ir 